\title{
Soil Water Tension, a Powerful Measurement for Productivity and Stewardship
}

\author{
Clinton C. Shock ${ }^{1,3}$ \\ Oregon State University, Malheur Experiment Station, 595 Onion Avenue, Ontario, OR 97914 \\ Feng-Xin Wang ${ }^{2}$ \\ Center for Agricultural Water Research in China, China Agricultural University, No. 17 Qinghua East Road, \\ Haidian, Beijing 100083, China
}

\begin{abstract}
Additional index words. irrigation, irrigation scheduling, Irrigas, soil water potential, tensiometer, granular matrix sensor,
\end{abstract} regulated deficit irrigation, dielectric coupled media

\begin{abstract}
A fundamental way to schedule irrigation is through the monitoring and management of soil water tension (SWT). Soil water tension is the force necessary for plant roots to extract water from the soil. With the invention of tensiometers, SWT measurements have been used to schedule irrigation. There are different types of field instruments used to measure SWT, either directly or indirectly. Precise irrigation scheduling by SWT criteria is a powerful method to optimize plant performance. Specific SWT criteria for irrigation scheduling have been developed to optimize the production and quality of vegetable crops, field crops, trees, shrubs, and nursery crops. This review discusses known SWT criteria for irrigation scheduling that vary from 2 to $800 \mathrm{kPa}$ depending on the crop species, plant product to be optimized, environmental conditions, and irrigation system. By using the ideal SWT and adjusting irrigation duration and amount, it is possible to simultaneously achieve high productivity and meet environmental stewardship goals for water use and reduced leaching.
\end{abstract}

Irrigated horticulture is essential for human health and welfare. Improved human nutrition can be achieved through improved horticultural productivity and quality, which in turn is often related to irrigation practices. Fresh water for horticulture production is increasingly in scarce supply and facing competition from alternative water demands from cities, industries, and interest groups that want water left in-stream to support fish and other aquatic organisms. Water quality is also becoming more important. It is widely recognized that precise irrigation is a key to high horticultural productivity, efficient water use, and water quality protection.

\section{OPTIONS FOR PRECISE IRRIGATION SCHEDULING}

There are several options for precise irrigation scheduling. One option is to schedule irrigations based on estimated crop evapotranspiration and replace the consumptive water use. A second option is to measure plant water stress and irrigate according to known plant yield and quality responses to water stress. Plant water stress can be measured either by the negative water potential in plant tissues or by the incremental heating of the crop canopy resulting from water stress. Other irrigation scheduling options rely on the measurement of

Received for publication 16 Sept. 2010. Accepted for publication 22 Nov. 2010.

This paper was part of the colloquium "Water Management and Plant Performance in a Changing Climate" held 4 Aug. 2010 at the ASHS Conference, Palm Desert, CA, and sponsored by the Water Utilization and Plant Performance in a Changing Climate (WUM) Working Group.

${ }^{1}$ Professor and Superintendent.

${ }^{2}$ Associate Professor.

${ }^{3}$ To whom reprint requests should be addressed; e-mail clinton.shock@oregonstate.edu and fxinwang@ yahoo.com.cn. soil water content or SWT. Soil water content can be determined through gravimetric, neutron probe, time domain reflectometry, or capacitance probe measurements. Measurements of soil water content can be particularly useful when soils are very uniform over large geographic expanses or uniform in nursery container mixes. Measurements of SWT can be determined with tensiometers, gypsum blocks, heat dissipation sensors, granular matrix sensors, psychrometers, and other devices. Measurements of SWT are particularly useful for irrigation scheduling when a SWT irrigation criterion that maximizes crop performance is determined for a given crop in a particular environment. When a SWT irrigation criterion is coupled with knowledge of the soil waterholding capacity, a planned increment of water can be applied at the right time, reducing the off-site effects of water movement. This review covers the equipment commonly used for SWT measurements and SWT irrigation criteria that have been determined for various crops.

\section{WHAT IS SOIL WATER TENSION AND HOW IT IS RELATED TO SOIL WATER POTENTIAL?}

Total soil water potential is defined as the amount of work per quantity of pure water that must be done by external forces to transfer reversibly and isothermally an infinitesimal amount of water from the standard state to the soil at the point under consideration. Soil water potential consists of the following components (Lei et al., 1988; Yong, 1999):

$\psi_{m}$, matric potential, pertaining to sorption forces between soil fractions and soil water; $\psi_{\pi}$, osmotic potential, equal to $\psi_{\mathrm{s}}$ (solute), referring to forces between solutes and water molecules;

$\psi_{g}$, gravitational potential, referring to position in the gravitational field; $\psi_{a}$, pneumatic (air) pressure, relating to pressures in the air phase;

$\psi_{p}$, pressure potential, primarily resulting from externally applied pressure transmitted through the fluid phase of the soil-water system.

In unsaturated soil, both $\psi_{p}$ and $\psi_{a}$ are negligible. If the soil depths are roughly the same, $\psi_{\mathrm{g}}$ can be ignored. Therefore, of the various components of the soil water potential $(\psi)$ that are responsible for the waterholding capacity of soils, the matric potential and $\psi_{\mathrm{s}}$ are most often considered as being sufficient to describe the water potential in partially saturated soil under constant uniform temperature and in the absence of externally applied gradients (Yong, 1999). Soil water potential is a negative number, because both $\psi_{m}$ and $\psi_{\mathrm{s}}$ are negative.

Soil water tension or soil suction usually refers to the absolute value of the sum of $\psi_{m}$ and $\psi_{\mathrm{s}}$, roughly the absolute value of the soil water potential under many field conditions. For many non-saline soils, $\left|\psi_{\mathrm{s}}\right|$ is much less than $\left|\psi_{m}\right|$ (Baker and Frydman, 2009). In this case, SWT is approximately equal to $\left|\psi_{m}\right|$ (Lei et al., 1988). Theoretical differences between soil water tension and soil water potential have been reviewed by others (Baker and Frydman, 2009; Yong, 1999).

\section{WHY MEASURE SOIL WATER TENSION}

The measurement of soil water tension can be closely related to the stress experienced by plant tissues. The need for water in the aboveground plant parts results in tension being transmitted to the roots to extract more water from the soil. In these conditions, irrigation scheduling based on soil water tension can be directly related to plant performance. The use of a soil water tension measuring device provides a continuous measurement analogous 
to the force (suction) necessary to extract water from the soil.

Soil water tension is closely related to plant stress, and crop yield and quality are closely related to SWT irrigation criteria (Shock et al., 2007b). Both product yield and quality are lost with too infrequent, heavy irrigation (Tjosvold and Schulbach, 1991). The nutrients lost in the excess irrigation water have the potential to contaminate groundwater and surface water. Careful irrigation scheduling by SWT provides the grower with techniques to simultaneously optimize income and minimize negative offsite effects of irrigation.

\section{INSTRUMENTS TO MEASURE SOIL WATER TENSION}

Soil water tension has been measured directly with tensiometers and through indirect methods such as with gypsum blocks, heat dissipation sensors, granular matrix sensors (GMS; Watermark), porcelain resistance to air movement (Irrigas), thermocouple psychrometers, pressure plates, and dielectric coupled porous media (MPS-1). Each type of instrument has certain strengths and limitations. What follows are the key points for each type of instrument. A pressure plate is useful to evaluate field samples taken to a laboratory, but delays in the availability of results compromise the use of pressure plate measurements for irrigation scheduling, so it is not discussed. Heat dissipation sensors can be calibrated to SWT (Campbell and Gee, 1986), but they are rarely used in production systems and are not discussed.

\section{Tensiometers}

A tensiometer is a sealed, water-filled device that exchanges water with the soil through a porcelain cup (Cassel and Klute, 1986; Hubbell and Sisson, 2003; Smajstrla and Koo, 1986). As plants remove water from the soil, water is drawn from the porcelain cup, developing a partial vacuum in the tensiometers. The partial vacuum is registered as $\mathrm{kPa}[\mathrm{kPa}=$ centibars (cbar)] of soil water tension on a mechanical gauge or through an electronic output device. Given the theoretical considerations and limitations discussed, tensiometers provide a direct measurement (the physical force that plants exert removing water from the soil) of soil water tension from 0 to $85 \mathrm{kPa}$. Tensiometers do not require site-specific calibrations. Tensiometers last for many years and they can be repaired.

Tensiometers are suitable for manual or electronic data collection. Manual reading of a tensiometer gauge requires no electrical power. Tensiometers can be equipped with pressure transducers or other devices for automatic readings (Cassel and Klute, 1986; Hubbell and Sisson, 2003; Strebel et al., 1973).

Tensiometers are susceptible to damage (Cassel and Klute, 1986; Smajstrla and Koo, $1986)$ if proper procedures are not followed during routine maintenance. Maintenance requires regular refilling with water and careful removal of air by pumping the air from the water column. When soils are allowed to dry to higher readings, water in the tensiometer must be replenished and air removed. Tensiometers require protection from freezing by covering, removal from the field, draining, or filling with $25 \%$ isopropyl alcohol, depending on the severity of the freezing weather.

Tensiometers can be accurate (especially when carefully and consistently built) and the responsiveness is enhanced with a smaller tensiometer size for potted plants and with a ceramic cup with greater conductivity (Cassel and Klute, 1986). Tensiometers with enhanced responsiveness are recommended for highly stress-sensitive crops grown in coarse or artificial soil mixes (Oki et al., 1995). Coarsetextured soils and artificial potting mixes often have less direct contact with the ceramic cup, so tensiometers with higher cup conductivities are more apt to accompany the rapid water tension changes in these media.

\section{Granular matrix sensors}

Granular matrix sensors provide indirect measurements of soil water tension. Granular matrix sensors measure a resistive value between two electrodes placed in a consistent granular matrix (Hawkins, 1993; Larson, 1985). The resistance is read using a half bridge circuit and is related to soil water tension using a standard calibration relationship (Shock, 2003). The Watermark Soil Moisture Sensor Model 200SS is a GMS marketed by the Irrometer Co., Inc., Riverside, CA.

Granular matrix sensors have advantages of low cost, no maintenance, and adaptability to widely variable wiring lengths. They are easy to read manually or through automation using battery-powered meters or data loggers. Site-specific calibration is usually not required and they are useful on most soil types. Sensor responsiveness is fairly rapid from 10 to $80 \mathrm{kPa}$, but tensiometers may respond more quickly to changes in SWT up to $50 \mathrm{kPa}$. Granular matrix sensors' useful range may extend to $200 \mathrm{kPa}$ or beyond with appropriate calibration. Sensors do not need to be protected from freezing and sensors may last several years.

Granular matrix sensors are not repairable, their calibration is less accurate from 0 to $10 \mathrm{kPa}$ than from 10 to $80 \mathrm{kPa}$, and the accuracy of granular matrix sensors can be less than tensiometers. The temperature dependence of the Watermark Model 200SS is known, so temperature compensation factors can be used in the calibration equations in meters and data loggers to improve the accuracy of Watermark SWT estimates (Shock, 2003).

\section{Gypsum blocks}

Gypsum blocks are another type of device that provides an indirect measurement of soil water tension. The electrodes are placed in gypsum blocks with consistent composition and a resistive measurement is calibrated against soil water tension (Bouyoucos and Mink, 1947; Campbell and Gee, 1986; Gardner, 1986). Gypsum blocks must be calibrated to
SWT in pressure plates or by some other method.

Gypsum blocks have relatively slow response times to changes in SWT compared to tensiometers and granular matrix sensors. The gypsum block tends to dissolve over time, so the block properties change. Gypsum block readings are influenced by temperature, changes in the soil solution concentration, and poor contact of the block with the soil (Campbell and Gee, 1986).

\section{Air permeability of porous ceramics}

Air permeability of porous ceramics has been used to estimate SWP (Kemper and Amemiya, 1958). Air permeability of a specific porous ceramic is a function of its water content. As water dries from the ceramic, the pores allow the passage of air. The "initial bubbling pressure" (IBP) of a water-saturated porous ceramic is the lowest applied pressure at which air permeability is observed (Pereira et al., 2005).

The IBP of a specific porous ceramic can be used to estimate whether a soil has reached the specific SWP used as an irrigation criterion. The National Center for Horticultural Research of EMBRAPA, Brazil, used IBP to develop Irrigas ${ }^{\circledR}$ to measure SWT (Calbo, 2004; Calbo and Silva, 2006; Marouelli and Calbo, 2009; Paschold and Mohammed, 2003). Irrigas is a pneumatic system to read soil water tension as a difference between the bubbling pressure of a porous cup and the smallest pressure needed to force air out of the cup. The Irrigas consists of a porous ceramic cup, a flexible tube, a transparent barrel, a rigid thin plastic support, and a moveable container of water. The porous ceramic cup is installed in the effective rooting zone of the crop and connected to a small transparent barrel by means of the flexible tube. The porous ceramic cup is designed to avoid free air movement out of the cup until the soil and cup reach a predetermined water potential. To make a reading, the barrel is immersed in the container of water. The free air passage through the porous ceramic cup gets blocked whenever the soil water saturates the pores in the ceramic. As the soil dries, its moisture drops below a critical tension value, and the porous cup becomes permeable to air passage. In dry soils when the barrel is immersed into the water, the meniscus (air-water boundary) rapidly moves upward in the barrel to equalize it to the water level in the container. Whenever water enters the barrel, the soil is at least as dry as the calibration of the porous ceramic cup.

Irrigas' strengths include operation with low maintenance, a linear response to soil water tension, and no water column height corrections needed (as required for tensiometers). The Irrigas can be built to attend different water tension ranges, according to the crop requirements, even for water tensions above $100 \mathrm{kPa}$, and can be used for accurate measurements in coarse-textured soils. A limitation is that in its most simple configuration, the Irrigas sensor only indicates that the soil water tension is above or below a critical water tension value 
used to define the moment to irrigate. Irrigas requires a pneumatic control of air flux to make continuous measurements or to automate irrigation, but the tubes for air flux can serve various sensors.

\section{Thermocouple psychrometers}

A thermocouple psychrometer works by measuring the vapor phase of water in the air in equilibrium with the liquid phase in a plant or soil sample (Oosterhuis 2003a, 2003b; Rawlings and Campbell, 1986). If temperature gradients are eliminated, accurate measurements can be made over the SWT range of 0.5 to 20 or more $\mathrm{MPa}$. As a result of the range of plant responses to irrigation, SWT measurements below $0.5 \mathrm{MPa}(500 \mathrm{kPa})$ are usually most useful for irrigation scheduling. In these wetter soils, changes in the vapor pressure of water in air in equilibrium with the soil are very small. Extremely accurate readings, highly representative samples, and the elimination of temperature gradients are all required to accurately estimate SWT. These conditions are not easily met under field conditions.

\section{Dielectric coupled media}

The MPS-1 Dialectic Water Potential Sensor (Decagon Devices, Inc., Pullman, WA) determines the soil water potential by measuring the dielectric permittivity or charge storage capacity of a porous ceramic using the ceramic's soil water characteristic curve (SWCC). Specifically, the MPS-1 measures water content by analyzing the charge stored when a high-frequency electromagnetic field is applied to the ceramic (Decagon Devices, 2008). Assuming the pore size distribution of each ceramic in every sensor is similar, the water content reading can be converted directly to water potential through a calibration based on the ceramic's SWCC. During production, the ideal is for each sensor to be individually dialed in to provide a consistent measurement of water potential over a range from $-10 \mathrm{kPa}$ to $\approx-500 \mathrm{kPa}$. A dialectic coupled media sensor must be calibrated to other measurements of SWT.

Ideally, a dialectic coupled media sensor would provide a wide range of water potential measurements for irrigation scheduling with no field maintenance, easy installation, and simple measurement circuitry. A disadvantage is that the current model is only moderately accurate across its water potential range. The air entry potential limits measurements in the wet range $(-10 \mathrm{kPa})$, and the dry range is limited to $-500 \mathrm{kPa}$.

\section{SENSOR PLACEMENT}

Sensors need to be placed in sensitive and representative locations in the crop root zone. Soil water tension varies in three dimensions over time. To choose where to place sensors, the variability in soil wetting from irrigation and rainfall and soil drying from evaporation and root water extraction for plant transpira- tion must be considered (Stieber and Shock, 1995). How to use fewer sensors to characterize soil water status and how to place these sensors is always a concern.

Sensor placement involves sensor depth in the soil, the distance from plant stems and the most wetted soil volume, and locations convenient for cultivation. As a result of the variability in roots' water uptake, surface evaporation, and partial soil wetting, there may be considerable spatial-temporal variability of soil water, particularly pronounced with drip irrigation. Haise and Hagan (1967) recommended placing two sensors at the top and bottom of the active rooting layers. Some researchers (Levin et al., 1985; Phene and Howell, 1984) suggested placing sensors adjacent to emitters. Many researchers have placed sensors at $15-$ to $30-\mathrm{cm}$ depth based on the effective rooting depth of the crop and the soil wetting patterns. For drip-irrigated potato, Wang et al. (2007) recommended placing the sensors at $20-\mathrm{cm}$ depth immediately under the dripper based on the observed spatial-temporal changes of soil matric potential. Stieber and Shock (1995) found that the representative sensor positions in sprinklerirrigated potato were between plants offset $15 \mathrm{~cm}$ from the top of the potato rows and 10 to $20 \mathrm{~cm}$ deep. Holler (2008) studying wine grapes (Vitis spp.) on clay found $60 \mathrm{~cm}$ to be a reliable sensor depth and $30 \mathrm{~cm}$ to be unreliable. Others have used SWT values based on the averages of multiple depths (Lynch and Tai, 1989; Serrano et al., 1992; Taylor et al., 1959).

\section{THE RESPONSE OF CROPS TO IRRIGATION SCHEDULING BY SOIL WATER TENSION}

The specific SWT irrigation criterion chosen for each crop should be based on experience with that crop in a given region. For any crop, the climate, soil type, irrigation system, and sensor placement affect the optimal irrigation criterion. Rainfall is the major climatic factor that affects the soil water regime and thus irrigation scheduling. Experiments on the North China Plain for tomato (Lycopersicon esculentum) suggest that when rain, rather than irrigation, is the main source of water and rainfall is relatively regular, a drier SWT irrigation criterion is the wise choice to take full advantage of rain (Wang et al., 2007a). The reported irrigation criteria for onion (Allium cepa) across environments are wetter at arid and semiarid locations (Table 1).

Soil type determines water-holding capacity. Clay soil holds more water than a sandy soil at the same SWT. When the same amount of water is depleted, SWT of the sandy soil increases much more rapidly than in the clay soil, which means earlier possible water stress for a crop on sandy soil.

Irrigation systems and their management determine water application rates and influence soil wetting patterns. Compared with drip and other partial soil wetting irrigation techniques, flood irrigation, control basin irrigation, and complete field furrow irrigation usually have greater irrigation depth and nearly all the topsoil is wetted. Some sprinkler irrigation systems are managed to wet all the topsoil. When the soil is soaked, deep-rooted crops have greater access to soil water. In addition, flood irrigation, control basin, and furrow irrigation are generally used to apply infrequent irrigations, making it impossible to both maintain low SWT and avoid deep percolation. Therefore, for these irrigation systems, it is expected that research would find a higher SWT irrigation criterion than for drip irrigation.

\section{Crops respond differently to soil water tension}

Onion. Onion is a shallow-rooted crop requiring relatively wet soil. Onion response to SWT was included in a review of vegetable crop irrigation (Shock et al., 2007b). For short-day onion, the irrigation criterion has varied from 8.5 to $45 \mathrm{kPa}$ depending on the climate, soil, and irrigation system (Table 1). Sandy soil and drip irrigation systems necessitate wetter irrigation criteria. When and where rainfall is significant, onion production is favored by slightly drier irrigation criteria. The irrigation criterion for long-day onions on silt loam has varied from 10 to $27 \mathrm{kPa}$. When rainfall is absent, wetter criteria are favored (Shock et al., 1998a). Furrow irrigation requires drier criteria than drip irrigation due to the risk of bulb decomposition in excessively wet parts of fields. Intentionally increasing water stress (increased SWT) in the latter part of the season in an attempt to reduce onion bulb decomposition failed to

Table 1. Soil water tension (SWT) as irrigation criteria for onion (Allium cepa) bulbs.

\begin{tabular}{|c|c|c|c|c|c|}
\hline $\begin{array}{l}\text { SWT } \\
(\mathrm{kPa})\end{array}$ & Location & Soil type & $\begin{array}{l}\text { Irrigation } \\
\text { system }\end{array}$ & $\begin{array}{l}\text { Soil moisture } \\
\text { sensors, depth }\end{array}$ & Citation \\
\hline$\overline{8.5}$ & Piauí, Brazil & Sandy & Microsprinkler & Tensiometer & Coelho et al., 1996 \\
\hline 10 & $\begin{array}{l}\text { Pernambuco, } \\
\text { Brazil }\end{array}$ & & Flood & $\begin{array}{l}\text { Tensiometer, } \\
\text { gravimetric }\end{array}$ & Abreu et al., 1980 \\
\hline 15 & $\begin{array}{l}\text { São Paulo, } \\
\text { Brazil }\end{array}$ & $\begin{array}{l}\text { Sandy and } \\
\text { clay }\end{array}$ & Furrow & Gravimetric & Klar et al., 1976 \\
\hline 10 to 15 & Oregon & Silt loam & Drip & GMS $20 \mathrm{~cm}$ & Shock et al., 2009 \\
\hline 17 to 21 & Oregon & Silt loam & Drip & GMS $20 \mathrm{~cm}$ & Shock et al., 2000a \\
\hline 27 & Oregon & Silt loam & Furrow & GMS $20 \mathrm{~cm}$ & Shock et al., 1998a \\
\hline 45 & $\begin{array}{l}\text { Karnataka, } \\
\text { India }\end{array}$ & $\begin{array}{l}\text { Sandy clay } \\
\text { loam }\end{array}$ & & $\begin{array}{l}\text { Tensiometer, } \\
\text { gravimetric }\end{array}$ & Hegde, 1986 \\
\hline 30 & Texas & $\begin{array}{l}\text { Sandy clay } \\
\text { loam }\end{array}$ & Drip & GMS $20 \mathrm{~cm}$ & Enciso et al., 2009 \\
\hline
\end{tabular}


improve bulb quality and reduced bulb yield and grade (Shock et al., 2000b). Onions are particularly sensitive to losses in yield and grade from small amounts of water stress when infected by iris yellow spot virus (Shock et al., 2009).

Potato. Potato is also shallow-rooted requiring relatively wet soil (Table 2). Precise irrigation of potato has been closely related to many tuber quality attributes (Shock et al., 2007a). The ideal irrigation criteria for potato on silt loam is often wetter ( 25 to $30 \mathrm{kPa}$ ) where drip irrigation is applied frequently (Kang et al., 2004; Shock et al., 2002c; Wang et al., 2007b) than where sprinkler or furrow irrigations systems are used (50 to $60 \mathrm{kPa}$ ) (Eldredge et al., 1992, 1996; Shock et al., 1993, 1998b, 2003, 2007a). Wetter irrigation criteria are needed on sandy soils than on silt loam soils. The ideal irrigation onset criteria for potato under sprinkler irrigation on sandy soils have been found to be 20 to $30 \mathrm{kPa}$ (Hegney and Hoffman, 1997; Lynch and Tai, 1989).

Cole crops. Cole crops (Brassica spp.) are among the species most sensitive to soil water tension (Table 3). Cole crops grown under arid conditions in Arizona with little rainfall respond to low SWT criteria. Irrigation criteria as wet as 6 to $12 \mathrm{kPa}$ are recommended for production on sandy loam in fall-winter in Arizona (Thompson and Doerge, 1995; Thompson et al., 2000a, 2000b, 2002a, 2002b). Broccoli grown in the spring at Agassiz, British Columbia, Canada, showed little difference in yields when grown at 20 or $30 \mathrm{kPa}$ all season compared with $50 \mathrm{kPa}$ during plant development followed by $20 \mathrm{kPa}$ during head formation (Maurer, 1976). The 50- to $20-\mathrm{kPa}$ treatment required less water. Cole crops grown under widely different conditions (Tifton, GA; Skierniewice, Poland; Bangalore, India) were more productive when irrigated at 20 to $40 \mathrm{kPa}$ than at 50 to $75 \mathrm{kPa}$ (Kaniszewski and Rumpel, 1998; Prabhakar and Srinivas, 1995; Smittle et al., 1992, 1994).

\section{Other field and vegetable crops}

The published SWT irrigation criteria for many other crops are listed in Table 4. In the case of sweetpotato (Ipomea batatas), the recommendation is to irrigate at $25 \mathrm{kPa}$ during early plant development and then switch to $100 \mathrm{kPa}$, a much drier criterion for potato development. These recommendations contrast with potato (Solanum tuberosum), in which the soil is maintained at a more constant SWT throughout development and some limited stress during early vegetative plant growth favors potato vine health and tuber quality (Cappaert et al., 1994; Shock et al., 1992).

Phene and Beale (1976) grew sweet corn (Zea mays) at 10, 20, and $40 \mathrm{kPa}$ measured $15 \mathrm{~cm}$ below corn plants with tape, furrow, and sprinkler irrigation systems on sandy soil on the coastal plains of South Carolina. Soil water tension irrigation criteria were managed using heat dissipation sensors that had been previously calibrated to SWT. They sought to provide water and nutrients with the porous tube and minimize nutrient loss. Sweet corn yields did not differ between SWT irrigation criteria or irrigation systems, but less water was required and less nitrate was leached with tape. Rivera-Hernandez et al. (2010) recommended $30 \mathrm{kPa}$ for sweet corn grown in Mexico; Rhoads and Stanley (1973) recommended $30 \mathrm{kPa}$ for corn grown for grain in Florida.

Thomson and Fisher (2006) used a SWT irrigation criterion of $60 \mathrm{kPa}$ for developing evapotranspiration (ET) irrigation scheduling for cotton (Gossypium hirsutum) in Mississippi.

Poplar trees. Hybrid poplar tree (Populus deltoides $\times P$. nigra) growth was measured with variable SWT on silt loam in semiarid eastern Oregon (Shock et al., 2002a). Rooting was mostly in the 0 - to $30-\mathrm{cm}$ layer and SWT

Table 2. Soil water tension (SWT) as irrigation criteria for potato (Solanum tuberosum).

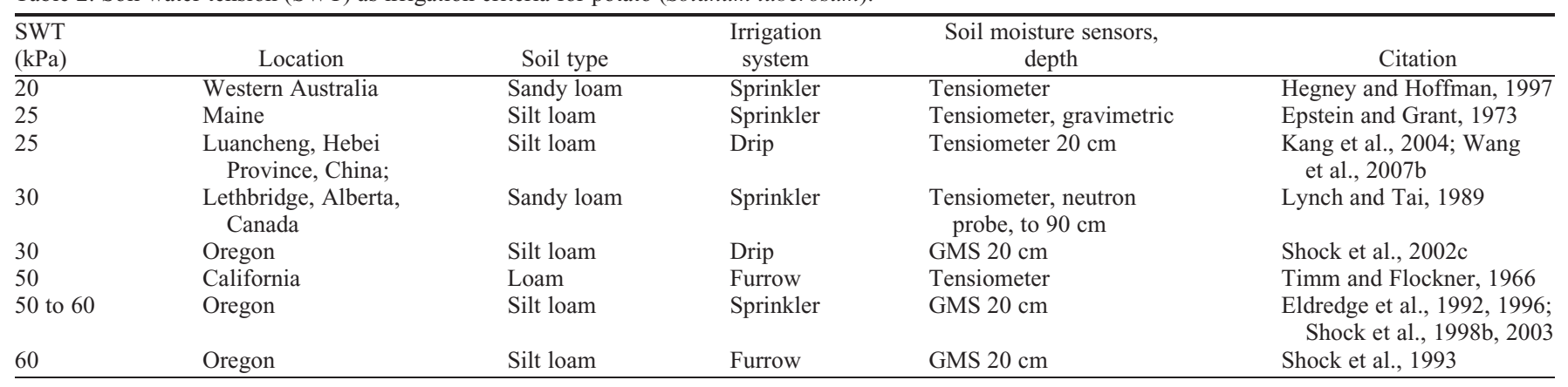

Table 3. Soil water tension (SWT) as irrigation criteria for cole crops (Brassica spp.).

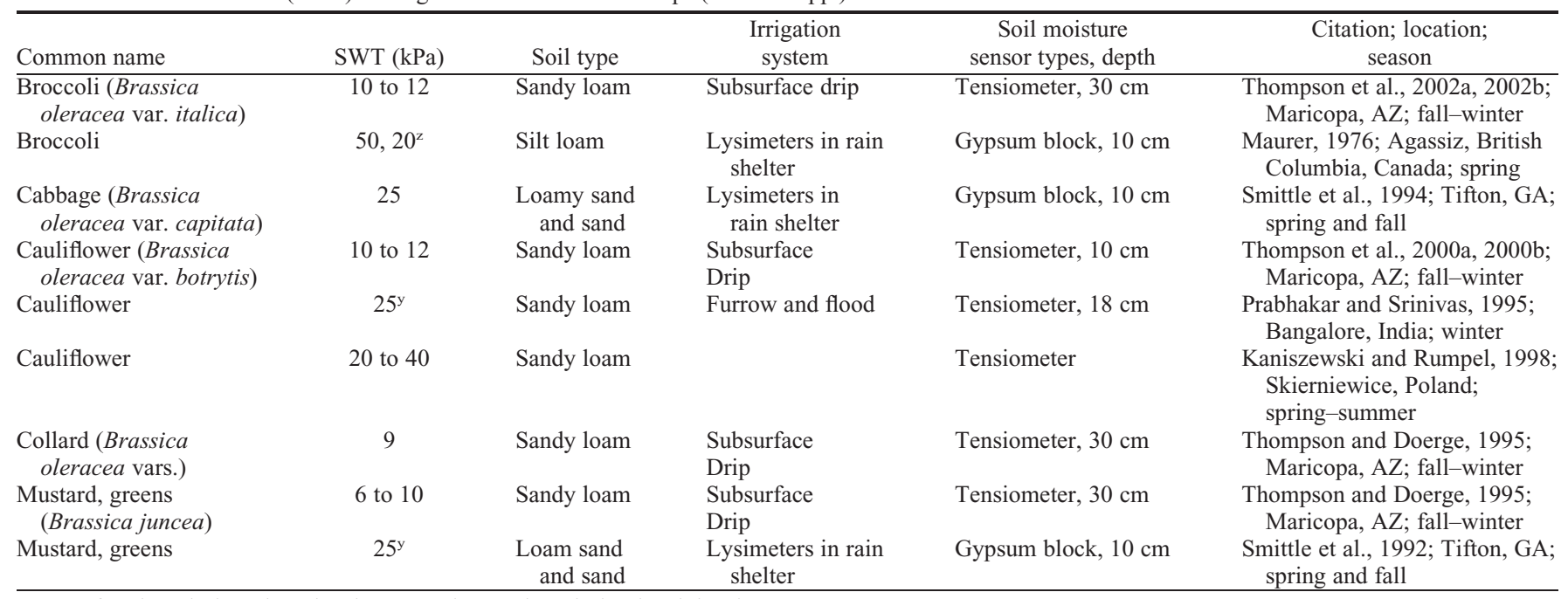

${ }^{\mathrm{z}} \mathrm{SWT}$ of $50 \mathrm{kPa}$ during plant development, then $20 \mathrm{kPa}$ during head development.

${ }^{\mathrm{y}}$ Twenty-five $\mathrm{kPa}$ was the wettest irrigation criterion tested. 


\begin{tabular}{|c|c|c|c|c|c|}
\hline Common name & SWT $(\mathrm{kPa})$ & Soil type & $\begin{array}{l}\text { Irrigation } \\
\text { system }\end{array}$ & $\begin{array}{l}\text { Soil moisture sensor } \\
\text { types, depth }\end{array}$ & Citation; location; season \\
\hline $\begin{array}{l}\text { Alfalfa grown for seed, } \\
\text { (Medicago sativa) }\end{array}$ & $200-800$ & $\begin{array}{l}\text { Fine sandy loam, } \\
\text { loam, silt loam }\end{array}$ & $\begin{array}{l}\text { Sprinkler and } \\
\text { surface flood }\end{array}$ & $\begin{array}{l}\text { Tensiometer and gypsum } \\
\text { block, } 10 \text { to } 183 \mathrm{~cm}\end{array}$ & $\begin{array}{l}\text { Taylor et al., 1959; Logan, UT; summer } \\
\text { season of the perennial crop }\end{array}$ \\
\hline $\begin{array}{l}\text { Beans, snap } \\
\quad \text { (Phaseolus vulgaris) }\end{array}$ & $25^{z}$ & Loamy sand & $\begin{array}{l}\text { Lysimeters in a } \\
\text { rain shelter }\end{array}$ & Gypsum block, $10 \mathrm{~cm}$ & $\begin{array}{l}\text { Stansell and Smittle, 1980; Tifton, GA; } \\
\text { spring and fall seasons }\end{array}$ \\
\hline Beans, snap & 45 & Sandy clay loam & & Tensiometer, $15 \mathrm{~cm}$ & $\begin{array}{l}\text { Hegde and Srinivas, 1990; Bangalore, } \\
\text { India; fall-winter }\end{array}$ \\
\hline Beans, snap & 50 & Clay loam & Furrow and drip & $\begin{array}{l}\text { Tensiometer and gypsum } \\
\text { block, } 30 \mathrm{~cm}\end{array}$ & $\begin{array}{l}\text { Muirhead and White 1981; Griffin, } \\
\text { NSW, Australia; summer }\end{array}$ \\
\hline $\begin{array}{l}\text { Carrot (Daucus carota } \\
\quad \text { var. sativa) }\end{array}$ & 30 to 50 & & Sprinkler & $\mathrm{TDR}^{\mathrm{y}}$ & $\begin{array}{l}\text { Lada, 2002; Nova Scotia, Canada; } \\
\text { spring-summer }\end{array}$ \\
\hline Carrot & 40 to 50 & & Microsprinkler & GMS, $15 \mathrm{~cm}$ & $\begin{array}{l}\text { Lada and Stiles, 2004; Nova Scotia, } \\
\text { Canada; spring-summer }\end{array}$ \\
\hline Celery (Apium graveolens) & 10 & Sandy loam & Drip & Tensiometer, $20 \mathrm{~cm}$ & $\begin{array}{l}\text { Feigin et al., 1982; Santa Ana, CA; } \\
\text { fall-winter }\end{array}$ \\
\hline $\begin{array}{l}\text { Corn for sweet corn } \\
\quad(\text { Zea mays })\end{array}$ & 10 to 40 & Sand & Drip & $\begin{array}{l}\text { Heat dissipation sensor } \\
\text { calibrated to SWT, } \\
15 \mathrm{~cm}\end{array}$ & Phene and Beale, 1976 \\
\hline Corn for sweet corn & 30 & Carstic soils & Drip & Tensiometer, $30 \mathrm{~cm}$ & $\begin{array}{l}\text { Rivera-Hernandez, et al., 2010; } \\
\text { Champoton, Campeche, Mexico; } \\
\text { spring-summer }\end{array}$ \\
\hline Corn for grain & 30 & Loamy fine sand & Sprinkler & Tensiometer, $15 \mathrm{~cm}$ & $\begin{array}{l}\text { Rhoads and Stanley, 1973; Quincy, } \\
\text { FL, spring-summer }\end{array}$ \\
\hline $\begin{array}{l}\text { Cucumber (Cucumis } \\
\text { sativus) }\end{array}$ & $15-30$ & $\begin{array}{l}\text { Fine sand and } \\
\text { sandy clay }\end{array}$ & Drip & Tensiometer, $20 \mathrm{~cm}$ & $\begin{array}{l}\text { Suojala-Ahlfors and Salo, 2005; } \\
\text { Piikkio, Finland; spring-summer }\end{array}$ \\
\hline $\begin{array}{l}\text { Lettuce, romaine } \\
\qquad(\text { Lactuca sativa })\end{array}$ & $<6.5$ & Sandy loam & Subsurface drip & Tensiometer, $30, \mathrm{~cm}$ & $\begin{array}{l}\text { Thompson and Doerge, 1995; } \\
\text { Maricopa, AZ; fall-winter }\end{array}$ \\
\hline Lettuce, leaf & $6-7$ & Sandy loam & Subsurface drip & Tensiometer, $30 \mathrm{~cm}$ & $\begin{array}{l}\text { Thompson and Doerge, 1996a, 1996b; } \\
\text { Maricopa, AZ; fall-winter }\end{array}$ \\
\hline Lettuce & $<10$ & Red earth & Drip & Tensiometer, $30 \mathrm{~cm}$ & Sutton and Merit, 1993; NSW, Australia \\
\hline Lettuce & 20 & $\begin{array}{l}\text { Clay loam, } \\
\text { sandy loam }\end{array}$ & Sprinkler, drip & Tensiometer, $15 \mathrm{~cm}$ & $\begin{array}{l}\text { Sammis, 1980; Las Cruces, NM; } \\
\text { summer-fall }\end{array}$ \\
\hline Lettuce, romaine & $30^{\mathrm{z}}$ & Clay loam & Surface & $\begin{array}{l}\text { Tensiometer and gypsum } \\
\text { block, } 30 \mathrm{~cm}\end{array}$ & Aggelides et al., 1999 \\
\hline $\begin{array}{l}\text { Lettuce, crisphead and } \\
\text { romaine }\end{array}$ & 50 & Sandy loam & Sprinkler & Tensiometer, $15 \mathrm{~cm}$ & $\begin{array}{l}\text { Gallardo et al., 1996; Salinas, CA; } \\
\text { spring-summer }\end{array}$ \\
\hline $\begin{array}{l}\text { Radish (Raphanus } \\
\text { sativus) }\end{array}$ & 35 & Silt loam & Drip & Tensiometer, $20 \mathrm{~cm}$ & $\begin{array}{l}\text { Kang and Wan, 2005; Luancheng, } \\
\text { Hebei Province, China; summer-fall }\end{array}$ \\
\hline Radish & 20 & Sandy clay loam & $\begin{array}{r}\text { Control basin } \\
\text { and furrow }\end{array}$ & Tensiometer, $18 \mathrm{~cm}$ & Hegde, 1987; Bangalore, India; winter \\
\hline Rice (Oryza sativa) & 16 & Sandy loam & Flood & Tensiometer, 15 to $20 \mathrm{~cm}$ & $\begin{array}{l}\text { Kukal et al., 2005; Punjab, India; } \\
\text { summer-fall }\end{array}$ \\
\hline $\begin{array}{l}\text { Spinach (Spinacea } \\
\text { oleracea) }\end{array}$ & 9 & Sandy loam & Drip & Tensiometer & $\begin{array}{l}\text { Thompson and Doerge, 1995; } \\
\text { Maricopa, AZ }\end{array}$ \\
\hline $\begin{array}{l}\text { Squash, summer } \\
\text { (Cucurbita pepo) }\end{array}$ & $25^{z}$ & $\begin{array}{l}\text { Loamy sand } \\
\text { and sand }\end{array}$ & Lysimeter & Gypsum block & $\begin{array}{l}\text { Stansell and Smittle, 1989; Tifton, } \\
\text { GA; spring, summer, and fall seasons }\end{array}$ \\
\hline $\begin{array}{l}\text { Sweet potato } \\
\qquad \text { (Ipomea batatas) }\end{array}$ & 25 , then $100^{\mathrm{x}}$ & $\begin{array}{l}\text { Loamy sand } \\
\text { and sand }\end{array}$ & $\begin{array}{l}\text { Lysimeters in } \\
\text { rain shelters }\end{array}$ & Gypsum blocks, $23 \mathrm{~cm}$ & Smittle et al., 1990; Tifton, GA; summer \\
\hline $\begin{array}{l}\text { Tomato (Lycopersicon } \\
\text { esculentum) }\end{array}$ & 10 & Fine sand & Drip & Tensiometer, $15 \mathrm{~cm}$ & $\begin{array}{l}\text { Smajstria and Locascio, 1996; } \\
\text { Gainesville, FL; spring }\end{array}$ \\
\hline Tomato & 20 & Sand & Drip & Tensiometer, $15 \mathrm{~cm}$ & $\begin{array}{l}\text { Oliveira and Calado, 1996; Coruche, } \\
\text { Portugal; spring-summer }\end{array}$ \\
\hline Tomato & $12-35^{\mathrm{w}}$ & Clay & Drip & $\begin{array}{l}\text { Tensiometer, } 10 \text { to } \\
20 \mathrm{~cm}^{\mathrm{v}}\end{array}$ & $\begin{array}{l}\text { Marouelli and Silva, 2007; Federal } \\
\text { District, Brazil; fall-winter }\end{array}$ \\
\hline Tomato & 50 & Silt loam & Drip & Tensiometer, $20 \mathrm{~cm}$ & $\begin{array}{l}\text { Wang, et al., 2007a; Yougledian, } \\
\text { Tongzhou, Beijing, China; summer }\end{array}$ \\
\hline $\begin{array}{l}\text { Watermelon } \\
\text { (Citrullus vulgaris) }\end{array}$ & 7 to 12.6 & Sandy loam & Drip & Tensiometer, $30 \mathrm{~cm}$ & $\begin{array}{l}\text { Pier and Doerge, } 1995 \mathrm{a}, 1995 \mathrm{~b} ; \\
\text { Maricopa, AZ; spring-summer }\end{array}$ \\
\hline
\end{tabular}

${ }^{z}$ Twenty-five $\mathrm{kPa}$ or $30 \mathrm{kPa}$ was the wettest irrigation criterion tested.

${ }^{\mathrm{y}} \mathrm{TDR}=$ time domain reflectometry.

${ }^{\mathrm{x}} \mathrm{SWT}$ of 25 during plant development, then 100 during root enlargement.

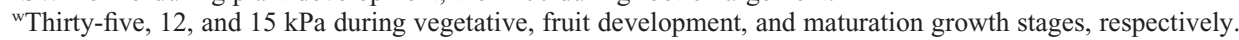

vTensiometer depth was $10 \mathrm{~cm}$ during the vegetative growth stage, $15 \mathrm{~cm}$ in the beginning of the fruit development stage, and $20 \mathrm{~cm}$ from thereon until the irrigations were stopped.

was measured with granular matrix sensors at 20 -cm depth. Growth was favored by an irrigation criterion of $25 \mathrm{kPa}$ compared with 50 and $75 \mathrm{kPa}$. Drier criteria led to reduced trunk and total biomass production.

Avocado. Richards et al. (1962) grew 'Haas' avocado (Persea americana) near Riverside, $\mathrm{CA}$, with sprinkler irrigations initiated at 50 , 100 , and $1000 \mathrm{kPa}$. Tensiometers and gypsum blocks were placed at $0.3-\mathrm{m}$ depth and at distances of 0.6 to $1.2 \mathrm{~m}$ from the tree trunk depending on tree size. Fruit production was not measureable during the years of the study as a result of wind damage. Tree trunk growth was greater with irrigations at $50 \mathrm{kPa}$. Irrigation criteria interacted with nitrogen fertilizer rate, moderating soil salinity (electrical conductivity) at $50 \mathrm{kPa}$ in the top foot of soil. Subsequent studies showed no differences in avocado fruit yield or tree growth between irrigation treat- ments at 50 and $150 \mathrm{kPa}$ (Warneke and Richards, 1972).

Cranberries. Jeranyama (2009) reports that cranberries (Vaccinium macrocarpon) require SWT in the range of 2 to $6 \mathrm{kPa}$ in the morning and 2 to $10 \mathrm{kPa}$ in the afternoon. Soil maintained consistently wetter than $2 \mathrm{kPa}$ during the growing season is too wet.

Strawberries. Strawberries (Fragaria $\times$ ananassa) are extremely sensitive to water 
stress. Serrano et al. (1992) grew strawberries in coastal Catalonia, Spain, at criteria of 10,30, 50 , and $70 \mathrm{kPa}$ under drip irrigation. The SWT was determined by the average of tensiometers at 10 - and $20-\mathrm{cm}$ depth and placed $15 \mathrm{~cm}$ from a drip emitter. Water application quantities were adjusted based on the soil water retention curve. Total strawberry yield and fruit per plant were greatest at 10 to $30 \mathrm{kPa}$. Average fruit size was greatest at $10 \mathrm{kPa}$.

\section{Flower production and ornamental plants in nurseries}

The production of nursery plants and flowers grown in artificial medium is particularly vulnerable to loss of water and nutrients from excessive amounts of irrigation and loss of yield from insufficient irrigation (Oki et al., 1995; Tjosvold and Schulbach, 1991). When artificial media is used as a potting mix, ornamental plants often benefit from the SWT being maintained in the range of 1 to $6 \mathrm{kPa}$ (Kiehl et al., 1992; Plaut et al., 1976). Plaut et al. (1976) showed that the artificial media at 15 - to 20-cm depth needs to be maintained at $5 \mathrm{kPa}$ or wetter for greenhouse production of cut roses (Rosa sp.). Using tensiometers, Oki et al. (1995) demonstrated that smaller irrigations at wetter SWT criteria resulted in greater rose productivity.

Carnations (Dianthus caryophyllus) grown in raised beds responded well with growth medium maintained in the 0 - to $10-\mathrm{kPa}$ range (Marsh et al., 1962). Leith and Burger (1989) automated tensiometers to control greenhouse irrigations and were able to improve chrysanthemum (Chrysanthemum $\times$ morifolium) production with criteria of 1.5 and $3.5 \mathrm{kPa}$ compared with slightly drier criteria. Kiehl et al. (1992) also demonstrated sensitive responses in chrysanthemum leaf, stem, and flower growth to small variations in SWT treatments controlled by automated tensiometer measurements. We conclude from the plant responses cited that tensiometers for many intensive greenhouse nursery crops need to be designed to be accurate and responsive in the 0 - to $10-\mathrm{kPa}$ range.

\section{Wine grapes and other examples of regulated deficit irrigation}

The management of a precise level of water stress to optimize a plant attribute is often referred to as regulated deficit irrigation. Recently the viticulturist of Camalie Vineyards, Napa, CA, demonstrated the usefulness of SWT data for the production of quality grapes on clay (Holler, 2008). Wine grapes are a case in which controlled and managed water stress is positively related to crop quality. The SWT measurements were made using granular matrix sensors at 30 - and 60-cm depths. Soil water tensions at $60 \mathrm{~cm}$ were significantly related to leaf water potential measurements. In the conditions of this vineyard, Holler determined that an irrigation criterion of $150 \mathrm{kPa}$ at $60 \mathrm{~cm}$ was closely related to stem water potentials known to optimize grape yield and quality. Delaying irrigation until the soil reached $150 \mathrm{kPa}$ resulted in water savings.

Hoffman et al. (1999) grew ornamental yew shrubs (Taxus $\times$ media) on silt loam in eastern Oregon and subjected the plants to water stress before harvesting leaves for the extraction of taxanes. Taxol is a yew taxane used as an anticancer pharmaceutical. Leaf taxane concentrations were greater when the soil was allowed to dry to 60 to $100 \mathrm{kPa}$ at 20 -cm depth before leaf harvest.

Alfalfa (Medicago sativa) grown for seed is known to respond positively to water stress. Taylor et al. (1959) demonstrated that the SWT in Logan, UT, for maximum seed production should be maintained in the range of 200 to $800 \mathrm{kPa}$ during flowering and seed formation (Table 4). Soil wetter than $200 \mathrm{kPa}$ resulted in too much vegetative growth, poor pollination, and little seed set, whereas soil drier than 800 $\mathrm{kPa}$ provoked excessive water stress. Trials were conducted on a wide range of soil types: fine sandy loam, loam, and silt loam.

\section{PRACTICAL APPLICATIONS AND AUTOMATION}

Tensiometers with pressure transducers have been used successfully to automate irrigations in greenhouses (Leith and Burger, 1989; Oki et al., 1995). Granular matrix sensors have been used in the field in automated systems that read sensors, calculate SWT, sort data, and control irrigations (Shock et al., 2002b). Automated systems can be as simple as recording a file of the actual field conditions or their readings can be used as feedback to control irrigations Gypsum blocks, dielectric coupled media (Decagon Devices, 2008; Ringler, 2009), heat dissipation sensors (Phene and Howell, 1984), and porous porcelain (Calbo, 2004) have all been used for automated systems.

\section{ENVIRONMENTAL IMPLICATIONS}

The existence of precise measurement of SWT in itself does not imply that irrigation water use will be optimized or that the off-site negative effects of leaching or runoff will be minimized. However, SWT measurements do allow these possibilities. Other considerations beyond the accurate reading of SWT such as the proper amount of water to apply and adequate or appropriate fertilization need to be integrated into a precise irrigation system to realize environmental protection.

The combination of irrigation scheduling by SWT and careful management of welldesigned irrigation systems can lead to highly efficient nitrogen fertilizer and water use (Feibert et al., 1998; Leith and Burger, 1989, Shock et al., 2004). Many of the other authors cited in this article for their SWT irrigation criteria were also simultaneously examining nitrogen or phosphorous fertilization practices to optimize production while reducing off-site effects.

Trials conducted in low rainfall environments demonstrated that irrigation in modest increments based on SWT plus rainfall closely matched the theoretical crop water demand based on estimated crop evapotranspiration $\left(E_{c}\right)$ (Feibert et al., 1998; Shock et al., 1998b, 2000a, 2004, 2009). When irrigation plus rainfall equals or is slightly less than $\mathrm{ET}_{\mathrm{c}}$, nitrogen $(\mathrm{N})$ use can be highly efficient because leaching is minimal, allowing the roots of the plants to have access to all $\mathrm{N}$ sources, be they residual available $\mathrm{N}$, mineralized $\mathrm{N}$, or $\mathrm{N}$ from fertilizer or irrigation water (Feibert et al., 1998; Shock et al., 2004).

\section{Literature Cited}

Abreu, T.A.S., A.A. Millar, E.N. Choudhury, and M.M. Choudhury. 1980. Analyses of onion production under variable irrigation [in Portuguese with English abstract]. Pesquisa Agropecu. Bras. 15:233-236.

Aggelides, S., I. Assimakopoulos, P. Kerkides, and A. Skondras. 1999. Effects of soil water potential on the nitrate content and yield of lettuce. Commun. Soil Sci. Plant Anal. 30:235-243.

Baker, R. and S. Frydman. 2009. Unsaturated soil mechanics - Critical review of physical foundations. Eng. Geol. 106:26-39.

Bouyoucos, G.J. and A.H. Mink. 1947. Improvements in the plaster of Paris absorption block electrical resistance method for measuring soil moisture under field conditions. Soil Sci. 63 : 255-265.

Calbo, A.G. 2004. Gas irrigation control system based on soil moisture determination through porous capsules. U.S. Patent 6705542 B2.

Calbo, A.G. and W.L.G. Silva. 2006. Gaseous irrigation control system: Description and physical tests for performance assessment. Bragantia 65:501-510.

Campbell, G.S. and G.W. Gee. 1986. Water potential: Miscellaneous methods, p. 619-633. In: Klute, A. (ed.). Methods of soil analysis, Part 1. Physical and mineralological methods. 2nd Ed. ASA-SSSA

Cappaert, M.R., M.L. Powelson, N.W. Christensen, W.R. Stevenson, and D.I. Rouse. 1994. Assessment of irrigation as a method of managing potato early dying. Phytopathology 84:792800

Cassel, D.K. and A. Klute. 1986. Water potential: Tensiometery, p. 563-596. In: Klute, A. (ed.). Methods of soil analysis, Part 1. Physical and mineralological methods. 2nd Ed. ASA-SSSA

Coelho, E.F., V.A.B. de Souza, and M.A.F Conceição. 1996. Onion yields under three water regimes and five spacings. Pesquisa Agropecu. Bras. 31:585-591.

Decagon Devices. 2008. MPS-1 dielectric water potential sensor (manual). Decagon Devices, Pullman, WA. 7 Nov. 2010. <http://www. ictinternational.com.au/brochures/decagon/mps1manual.pdf $>$.

Eldredge, E.P., Z.A. Holmes, A.R. Mosley, C.C. Shock, and T.D. Stieber. 1996. Effects of transitory water stress on potato tuber stem-end reducing sugar and fry color. Amer. Potato J. 73:517-530

Eldredge, E.P., C.C. Shock, and T.D. Stieber. 1992 Plot sprinklers for irrigation research. Agron. J. 84:1981-1984.

Enciso, J., B. Wiedenfeld, J. Jifon, and S. Nelson 2009. Onion yield and quality response to two irrigation scheduling strategies. Sci. Hort. 120: 301-305.

Epstein, E. and W.J. Grant. 1973. Water stress relations of the potato plant under field conditions. Agron. J. 65:400-404.

Feibert, E.B.G., C.C. Shock, and L.D. Saunders. 1998. Nitrogen fertilizer requirements of potatoes 
using carefully scheduled sprinkler irrigation. HortScience 32:262-265

Feigin, A., J. Letey, and W.M. Jarrell. 1982. Celery response to type, amount, and method of $\mathrm{N}$ fertilizer application under drip irrigation. Agron. J. 74:971-978.

Gallardo, M., L.E. Jackson, K. Schulbach, R.L. Snyder, R.B. Thompson, and L.J. Wyland. 1996. Production and water use in lettuces under variable water supply. Irrig. Sci. 16:125-137.

Gardner, W.H. 1986. Water content, p. 493-544. In: Klute, A. (ed.). Methods of soil analysis. Part 1. Physical and mineralogical methods. Agron. Ser. No. 9. Amer. Soc. Agron. 2nd Ed.

Haise, H.R. and R.M. Hagan. 1967. Soil, plant and evaporative measurements as criteria for scheduling irrigation, p. 577-604. In: Hagan, R.M., H.R. Haise, and T.W. Edminster (eds.). Irrigation of agricultural lands. ASA, Madison, WI.

Hawkins, A.J. 1993. Electrical sensor for sensing moisture in soils. U.S. Patent 5,179,347. Date issued: 12 Jan.

Hegde, D.M. 1986. Effect of irrigation regimes on dry matter production, yield, nutrient uptake and water use of onion. Indian J. Agron. 31:343348.

Hegde, D.M. 1987. Effect of soil matric potential, method of irrigation and nitrogen fertilization on yield, quality, nutrient uptake and water use of radish (Raphanus sativus L.). Irrig. Sci. 8: 13-22.

Hegde, D.M. and K. Srinivas. 1990. Plant water relations and nutrient uptake in French bean. Irrig. Sci. 11:51-56.

Hegney, M.A. and H.P. Hoffman. 1997. Potato irrigation-Development of irrigation scheduling guidelines. Final Report, Hort. Res. and Dev. Corporation Project NP 6. Agr. Western Australia.

Hoffman, A.M., C.C. Shock, and E.B.G. Feibert. 1999 Taxane and ABA production in yew under different soil water regimes. HortScience 34:882-885.

Holler, M. 2008. High density, multiple depth, wireless soil moisture tension measurements for irrigation management. Camalie Networks, Napa, CA. 8 Nov. 2010. <http://66.82.73.54/ High\%20Density,\%20Multiple\%20Depth,\%20 Wireless\%20Soil\%20Moisture.pdf>.

Hubbell, J.M. and J.B. Sisson. 2003. Soil water potential measurement by tensiometers, p. 904 907. In: Stewart, B.A. and T.A. Howell (eds.). Encycl. of Water Sci. Marcel Dekker, New York, NY.

Jeranyama, P. 2009. Irrigation water management, p. 53-54. In: Cranberry 2009 chart book, management guide for Massachusetts. Univ. of Mass. Amherst, Cranberry Sta., Amherst, MA.

Kang, Y., F.X. Wang, H.J. Liu, and B.Z. Yuan. 2004. Potato evapotranspiration and yield under different irrigation regimes. Irrig. Sci. 23: 133-143.

Kang, Y.H. and S.Q. Wan. 2005. Effect of soil water potential on radish (Raphanus sativus L.) growth and water use under drip irrigation. Sci. Hort. 106:275-292.

Kaniszewski, S. and J. Rumpel. 1998. Effects of irrigation, nitrogen fertilization and soil type on yield and quality of cauliflower. J. Veg. Crop Prod. 4:67-75.

Kemper, W.D. and M. Amemiya. 1958. Utilization of air permeability of porous ceramics as a measure of hydraulic stress in soils. Soil Sci. 85:117-124.

Kiehl, P.A., J.H. Lieth, and D.W. Burger. 1992. Growth response of chrysanthemum to various container medium moisture levels. J. Amer. Soc. Hort. Sci. 114:224-229.

Klar, E.A., J.F. Pedras, and J.D. Rodrigues. 1976. Effect of various soil and climatic conditions on water requirement of onion. I. Yield of bulbs. Phyton. 34:9-25.

Kukal, S.S., G.S. Hira, and A.S. Sidhu. 2005. Soil matric potential-based irrigation scheduling to rice (Oryza sativa). Irrig. Sci. 23:153-159.

Lada, R. 2002. Processing carrot research program. Nova Scotia Agr. College Dept. of Plant and Animal Sci. res. summary. Vol. 4, 2001-02.

Lada, R. and A. Stiles. 2004. Water requirement and irrigation management for optimizing carrot yield and quality. Nova Scotia Agric. College, Truro, Nova Scotia, Canada. Processing carrot research program fact sheet, PCRP Publ. 2004-03.

Larson, G.F. 1985. Electrical sensor for measuring moisture in landscape and agricultural soils. U.S. Patent 4531 087. Date issued: 23 July.

Lei, Z.D., S.X. Yang, and S.Z. Xie. 1988. Soil water dynamics [in Chinese]. Tsinghua Univ. Press, Beijing, China. p. 8-18.

Leith, J.H. and D.W. Burger. 1989. Growth of chrysanthemum using an irrigation system controlled by soil moisture tension. J. Amer. Soc. Hort. Sci. 114:387-392.

Levin, I., S. Sarig, and M. Meron. 1985. Tensiometers location in controlled automated drip irrigation of cotton. Proc. of the 3rd Intl. Drip/ Trickle Irrig. Congress.

Lynch, D.R. and G.C.C. Tai. 1989. Yield and yield component response of eight potato geneotypes to water stress. Crop Sci. 29:1207-1211.

Marouelli, W.A. and A.G. Calbo. 2009. Manejo de irrigação em hortaliças com sistema Irrigas ${ }^{\circledR}$. Brasília. Embrapa Hortaliças, Circular Técnica 69.

Marouelli, W.A. and W.L.C. Silva. 2007. Water tension thresholds for processing tomatoes under drip irrigation in Central Brazil. Irrig. Sci. 25:411-418.

Marsh, A.W., L.F. Werenfels, and R.N. Sciaroni. 1962. Advantages of tensiometer use in carnation irrigation. Florists' Rev. May:13, 14, 38, 39.

Maurer, A.R. 1976. Response of broccoli to five soil water regimes. Can. J. Plant Sci. 56:953-959.

Muirhead, W.A. and R.J.G. White. 1981. The influence of soil water potential on the flowering pattern, pod set and yield of snap beans (Phaseolus vulgaris L.). Irrig. Sci. 3:45-56.

Oki, L.R., J.H. Leith, and S. Tjosvold. 1995. Tensiometer-based irrigation of cut-flower roses. 1994 Project report to the Calif. Cutflower Commission.

Oliveira, M.R.G. and A.M. Calado. 1996. Tomato root distribution under drip irrigation. J. Amer. Soc. Hort. Sci. 121:644-648.

Oosterhuis, D.M. 2003a. Psychrometry for measuring plant and soil water status: Accuracy, interpretation, and sampling, p. 748-750. In: Stewart, B.A. and T.A. Howell (eds.). The Encycl. of Water Sci. Marcel Dekker, New York, NY.

Oosterhuis, D.M. 2003b. Psychrometry for measuring plant and soil water status: Theory, types, and uses, p. 751-755. In: Stewart, B.A. and T.A. Howell (eds.). The Encycl. of Water Sci. Marcel Dekker, New York, NY.

Paschold, P.J. and A. Mohammed. 2003. Irrigas: A new simple soil moisture sensor for irrigation scheduling. J. of Appl. Irrig. Sci., Germany. 38: 22-28.

Pereira, A.B., C.A. Shock, C.C. Shock, and E.B.G. Feibert. 2005. Use of Irrigas $\AA$ for irrigation scheduling for onion under furrow irrigation. Oreg. Sta. Univ. Agr. Expt Sta., spec. rpt. 1062: 223-229.

Phene, C.J. and O.W. Beale. 1976. High-frequency irrigation management for water and nutrient management in humid regions. Soil Sci. Soc. Amer. J. 40:430-436.
Phene, C.J. and T.A. Howell. 1984. Soil sensor control of high-frequency irrigation systems. Trans. ASAE 27:392-396.

Pier, J.W. and T.A. Doerge. 1995a. Concurrent evaluation of agronomic, economic, and environmental aspects of trickle-irrigated watermelon production. J. Environ. Qual. 24:79-86.

Pier, J.W. and T.A. Doerge. 1995b. Nitrogen and water interactions in trickle-irrigated watermelon. Soil Sci. Soc. Amer. J. 59:145-150.

Plaut, Z., N. Zieslin, and N. Levev. 1976. Effect of different soil moisture regimes and canopy wetting on 'Baccara' roses. Sci. Hort. 5:277-285.

Prabhakar, M. and K. Srinivas. 1995. Effects of soil matric potential and irrigation methods on plant water relations, yield and water use of cauliflower. J. Maharashtra Agr. Univ. 20:229-233.

Rawlings, S.L. and G.S. Campbell. 1986. Water potential: Thermocouple psychrometry, p. 597-618. In: Klute, A. (ed.). Methods of soil analysis, Part 1. Physical and mineralological methods. 2nd Ed. ASA-SSSA.

Rhoads, F.M. and R.L. Stanley. 1973. Response of three corn hybrids to low levels of soil moisture tension in the plow layer. Agron. J. 65:315318.

Richards, S.J., J.E. Warneke, and F.T. Bingham. 1962. Avocado tree growth in response to irrigation. Calif. Avocado Soc. 1962 Yearbook 46:8387. 15 Nov. 2010. <http://www.avocadosource. com/CAS_Yearbooks/CAS_46_1962/CAS_1962_ PG_83-87.pdf>.

Ringler, J.W. 2009. Monitoring the hydrology of soils for on-site wastewater treatment systems using matric potential sensors. MS Thesis, Ohio State Univ. 7 Nov. 2010. <http://etd.ohiolink.edu/ send-pdf.cgi/Ringler\%20Joseph\%20William.pdf? osu1243013245>.

Rivera-Hernandez, B., E. Carrillo-Avila, J.J. ObradorOlan, and L.A. Aceves-Navarro. 2010. Morphological quality of sweet corn (Zea mays L.) ears as response to soil moisture tension and phosphate fertilization in Campeche, Mexico. Agr. Water Mgt. 97:1365-1374.

Sammis, T.W. 1980. Comparison of sprinkler, trickle, subsurface and furrow irrigation methods for row crops. Agron. J. 72:701-704.

Serrano, L., X. Carbonell, R. Savé, O. Marfà, and J. Peñuelas. 1992. Effects of irrigation regimes on the yield and water use of strawberry. Irrig. Sci. 13:45-48.

Shock, C.C. 2003. Soil water potential measurement by granular matrix sensors, p. 899-903. In: Stewart, B.A. and T.A. Howell (eds.). The Encycl. of Water Sci. Marcel Dekker, New York, NY.

Shock, C.C., E.B.G. Feibert, and L.D. Saunders. 1998a. Onion yield and quality affected by soil water potential as irrigation threshold. HortScience 33:1188-1191.

Shock, C.C., E.B.G. Feibert, and L.D. Saunders. 1998b. Potato yield and quality response to deficit irrigation. HortScience 33:655-659.

Shock, C.C., E.B.G. Feibert, and L.D. Saunders. 2000a. Irrigation criteria for drip-irrigated onions. HortScience 35:63-66.

Shock, C.C., E.B.G. Feibert, and L.D. Saunders. 2000 b. Onion storage decomposition unaffected by late-season irrigation reduction. HortTechnology 10:176-178.

Shock, C.C., E.B.G. Feibert, and L.D. Saunders. 2003. Umatilla Russet and Russet Legend potato yield and quality response to irrigation. HortScience 38:1117-1121.

Shock, C.C., E.B.G. Feibert, and L.D. Saunders. 2004. Plant population and nitrogen.fertilization for subsurface drip-irrigated onion. HortScience 39:1722-1727. 
Shock, C.C., E.B.G. Feibert, L.D. Saunders, L.B. Jensen, S.K. Mohan, R.S. Sampangi, and H. Pappu. 2009. Management of onion cultural practices to control the expression of iris yellow spot virus. Oreg. Sta. Univ. Agr. Expt Sta., spec. rpt. 1094:41-60.

Shock, C.C., E.B.G. Feibert, M. Seddigh, and L.D. Saunders. 2002a. Water requirements and growth of irrigated hybrid poplar in a semi-arid environment in eastern Oregon. West. J. Appl. For. 17:46-53.

Shock, C.C., E.B.G. Feibert, L.D. Saunders, and E.P. Eldredge. 2002b. Automation of subsurface drip irrigation for crop research, p. 809816. In: Zazueta, F. and J. Xin (eds.). World Congress on Computers in Agr. and Natl. Resources; 13-15 Mar. 2002; Iguaçu Falls, Brazil. Amer. Soc. of Agr. Eng.

Shock, C.C., E.P. Eldredge, and L.D. Saunders. 2002c. Drip irrigation management factors for 'Umatilla Russet' potato production. Oreg. Sta. Univ. Agr. Expt Sta., spec. rpt. 1038:157-169.

Shock, C.C., Z.A. Holmes, T.D. Stieber, E.P. Eldredge, and P. Zhang. 1993. The effect of timed water stress on quality, total solids and reducing sugar content of potatoes. Amer. Potato J. 70:227-241.

Shock, C.C., A.B. Pereira, and E.P. Eldredge. 2007a. Irrigation best management practices for potato. In: Rosen, C. and M. Thornton (eds.). Symposium on best mgt. practices for nutrients and irrig.: Res., regulation, and future directions. Amer. J. Potato Res. 8429-37.

Shock, C.C., A.B. Pereira, B.R. Hanson, and M.D. Cahn. 2007b. Vegetable irrigation, p. 535-606. In: Lescano, R. and R. Sojka (eds.). Irrigation of agricultural crops. 2nd Ed. Agron. Monogr. 30. ASA, CSSA, and SSSA, Madison, WI.

Shock, C.C., J.D. Zalewski, T.D. Stieber, and D.S. Burnett. 1992. Early season water deficits on Russet Burbank plant development, yield, and quality. Amer. Potato J. 69:793-804.

Smajstrla, A.G. and R.C. Koo. 1986. Use of tensiometers for scheduling of citrus trickle irrigation. Proc. Fla. State Hort. Soc. 99:51-56.

Smajstrla, A.G. and S.J. Locascio. 1996. Tensiometercontrolled, drip-irrigation scheduling of tomato. Appl. Eng. Agr. 12:315-319.
Smittle, D.A., W.L. Dickens, and J.R. Stansell. 1994. Irrigation regimes affect cabbage water use and yield. J. Amer. Soc. Hort. Sci. 119:20-23.

Smittle, D.A., W.L. Dickens, J.R. Stansell, and E. Simonne. 1992. Irrigation regimes affect leaf yield and water use by turnip and mustard. HortScience 27:308-310.

Smittle, D.A., M.R. Hall, and J.R. Stansell. 1990. Irrigation regimes on yield and water use by sweetpotato. J. Amer. Soc. Hort. Sci. 115:712714.

Stansell, J.R. and D.A. Smittle. 1980. Effects of irrigation regimes on yield and water use of snap bean (Phaseolus vulgaris L.). J. Amer. Soc. Hort. Sci. 105:869-873.

Stansell, J.R. and D.A. Smittle. 1989. Effects of irrigation regimes on yield and water use of summer squash. J. Amer. Soc. Hort. Sci. 114: 196-199.

Stieber, T.D. and C.C. Shock. 1995. Placement of soil moisture sensors in sprinkler irrigated potatoes. Amer. Potato J. 72:533-543.

Strebel, O., M. Renger, and W. Geisel. 1973. Soil suction measurements for evaluation of vertical flow of greater depths with pressure transducer tensiometers. J. Hydrol. (Amst.) 18:367-370.

Suojala-Ahlfors, T. and T. Salo. 2005. Growth and yield of pickling cucumber in different soil moisture circumstances. Sci. Hort. 107:11-16.

Sutton, B.G. and N. Merit. 1993. Maintenance of lettuce root zone at field capacity gives best yields with drip. Scientia Hort. (Canterbury, England) 56:1-11.

Taylor, S.A., J.L. Haddock, and M.W. Pedersen. 1959. Alfalfa irrigation for maximum seed production. Agron. J. 51:357-360.

Thompson, T.L. and T.A. Doerge. 1995. Nitrogen and water rates for subsurface trickle-irrigated collard, mustard, and spinach. HortScience 30: 1382-1387.

Thompson, T.L. and T.A. Doerge. 1996a. Nitrogen and water interactions in subsurface trickleirrigated leaf lettuce: I. Plant response. Soil Sci. Soc. Amer. J. 60:163-168.

Thompson, T.L. and T.A. Doerge. 1996b. Nitrogen and water interactions in subsurface trickleirrigated leaf lettuce: II. Agronomic, economic, and environmental outcomes. Soil Sci. Soc. Amer. J. 60:168-173.

Thompson, T.L., T.A. Doerge, and R.E. Godin. 2000a. Nitrogen and water interactions in subsurface drip-irrigated cauliflower: I. Plant response. Soil Sci. Soc. Amer. J. 64:406411.

Thompson, T.L., T.A. Doerge, and R.E. Godin. 2000b. Nitrogen and water interactions in subsurface drip-irrigated cauliflower: II. Agronomic, economic, and environmental outcomes. Soil Sci. Soc. Amer. J. 64:412-418.

Thompson, T.L., T.A. Doerge, and R.E. Godin. 2002a. Subsurface drip irrigation and fertigation of broccoli. I. Yield, quality, and nitrogen uptake. Soil Sci. Soc. Amer. J. 66:186-192.

Thompson, T.L., T.A. Doerge, and R.E. Godin. $2002 \mathrm{~b}$. Subsurface drip irrigation and fertigation of broccoli. II. Agronomic, economic, and environmental outcomes. Soil Sci. Soc. Amer. J. $66: 178-185$.

Thomson, S.J. and D.K. Fisher. 2006. Calibration and use of the UGA EASY evaporation pan for low frequency sprinkler irrigation of cotton in a clay soil. J. Cotton Sci. 10:210-223.

Timm, H. and W.J. Flockner. 1966. Responses of potato plants to fertilization and soil moisture under induced soil compaction. Agron. J. 58: $153-157$.

Tjosvold, S.A. and K.F. Schulbach. 1991. How to reduce water use and maximize yields in greenhouse roses. Calif. Agr. (May-June):3132.

Wang, D., Y. Kang, and S. Wan. 2007a. Effect of soil matric potential on tomato yield and water use under drip irrigation condition. Agr. Water Mgt. 87:180-186.

Wang, F.X., Y.H. Kang, S.P. Liu, and X.Y. Hou. 2007b. Effects of soil matric potential on potato growth under drip irrigation in the North China Plain. Agr. Water Mgt. 88:34-42.

Warneke, J.E. and S.J. Richards. 1972. Avocado irrigation management. Calif. Avocado Soc. 197172 Yearbook 55:52-55. 10 Nov. 2010. <http:// www.avocadosource.com/CAS_Yearbooks/CAS 55_1971/CAS_1971-72_PG_052-055.pdf>.

Yong, R.N. 1999. Soil suction and soil-water potentials in swelling clays in engineered clay barriers. Eng. Geol. 54:3-13. 